This is an electronic version of an article published in Gallagher, K., \& Riviere, D. (2007). When drama praxis rocks the boat: Struggles of subjectivity, audience and performance. Research in Drama Education, 12(3), 319-330. Cognition and Instruction is available online at: www.tandfonline.com with

http://www.tandfonline.com/openurl?genre=article\&issn=1356-

$9783 \&$ volume $=12 \&$ issue $=3 \&$ spage $=319$

When Drama Praxis Rocks the Boat: struggles of subjectivity, audience, and performance

Kathleen Gallagher

Dominique Riviere 


\section{When Drama Praxis Rocks the Boat: struggles of subjectivity, audience, and performance}

\section{Introduction}

This article examines the particular strength of theatre to raise questions about relations of gender and race in a multicultural, urban high school and supports the 'rights' of youth and teachers to use drama to critique their cultural contexts. To build our argument, we will examine: i) the terms of communication, during a classroom discussion, about questions of race, identity and representation for a diverse group of grade twelve (17-18 years old) high school drama students in Toronto and ii) the ensuing school-wide 'fall-out' following the students' production of Jamaican-Canadian playwright Trey Anthony's Da Kink in my Hair (Anthony, 2001). We view the students' and teacher's educational and artistic struggles as closely connected to those struggles of broader political, cultural, and social democratic life (Giroux, 1992). We will, therefore, use these episodes to illustrate the ways in which theatre work in schools might productively interrupt conventional notions of 'multiculturalism'.

To theoretically ground the discussion of drama praxis at the centre of our examination, we take a critical perspective on the formation, and performance, of racialized and gendered identities. Further, we turn to such critical, anti-colonial thinkers as Dei, Karumanchery and Karumanchery-Luik (2004) ; Razack (1998); McCarthy, Crichlow and Dimitriadis (2005), Bhabha (1994), Giroux (1992) and Trinh (1989), in order to examine the uses of, and the risks of using, theatre in high schools to engage with, issues of social justice and citizenship. We agree 
with Giroux (1992) who writes that the pedagogical dimension of the teacher's role as a cultural worker:

[...] refers to the process of creating symbolic representations and the practices within which they're engaged. [...] The political dimension of cultural work informs this process through a project whose intent is to mobilize knowledge and desires that may lead to minimizing the degree of oppression in peoples' lives (p. 5, emphasis added).

The empirical work presented here is part of a larger ethnographic study (2002-2005) of high school drama classrooms in four public, urban schools: two in Toronto, Canada and two in New York City, USA ${ }^{1}$. The specific episodes to be examined in this paper took place at 'Middleview High School' (a pseudonym). Located in a mostly "poor/working class" neighbourhood in the central core of Toronto, Canada, Middleview High School (MHS) is a very ethno-culturally and linguistically diverse school. These social identity markers mean that the school is seen, in many ways, as a threat, as - in the words of one student - 'a ghetto school', fraught with danger, and overrun by violence. Because of this, MHS has a very disciplined and authoritarian ethos. For instance, there is a "no hats/headgear" policy (which means that students are not allowed to wear hats, bandanas, 'do rags', or any other kind of head covering that might suggest gang affiliation) and security guards patrol the halls during school hours. MHS has what Daniel Yon (2000) refers to as a "spoiled identity": that is, the dominant discourses about the nature of the school ('ghetto', violent, threatening) almost

\footnotetext{
${ }^{1}$ The work represented in this paper is based on Dr. Kathleen Gallagher's ethnographic study, Drama, Education, Youth \& Social Cohesion: (re)constructing identities in urban contexts for which Dominique Rivière was a research assistant from 2002-2005; gratitude to the Social Sciences and Humanities Research Council of Canada for their generous support of this study.
} 
completely obscure its much more complex and ambiguous reality as a site where moments of tension and of community exist simultaneously.

The particular episodes we have selected for analysis demonstrate the implications of challenging normative constructions of racial and gendered subjectivity within the context of youth performances, of both the social and artistic kind. To begin our exploration, we consider the constructs of 'performance' and 'audience reaction' in theatre, through an analysis of two critical episodes that occurred during our time at MHS: a heated, whole-class, discussion about the perils and possibilities of African History Month, from which we moved into a Boal-type dramatic exploration of power; and a series of responses - by students, teachers and administrators - to a student performance of scenes from Da Kink in My Hair. More specifically, we explore what happens when an attempt is made in theatre to turn the gaze upon the "Other" - and to turn the ear towards the "Other" - as subject, rather than object. That is, we examine how, in a school setting, the production and reception of dramatic works is influenced - but not necessarily determined - by the larger social context(s) that mark the limits of peoples' interactions, according to their particular social positionings (in this instance, most markedly the categories of race and gender) within unequal relations of power. Ultimately, we point to both the repressive, or 'backlash' audience responses, and the productive possibilities of these relationships, as explored through what is often termed 'controversial' drama. 


\section{African History Month: Identity, Representation, Citizenship, and Rights}

Our particular understandings of 'identity' and 'representation' are informed by McCarthy \& Crichlow (1993), who write that those concepts refer:

...to the question of the social power that resides in the specific arrangement of subjectivity in cultural and ideological practices in schooling and society. [...] Issues of identity and representation directly raise questions about who has the power to define whom, and when, and how (p. xvi, emphasis added).

Such a discussion that raised the contested question of 'social power' - in its various forms - occurred during the second phase of our research project at MHS. The classroom we were working in was a senior-level Drama class, consisting of about twenty students. Toronto's ethnocultural diversity was very much reflected in this class: the students came from Anglo-European, Caribbean, Eastern-European, Asian, continental African, and Southeast Asian (Indian and Pakistani) backgrounds. On the day in question - February $27^{\text {th }}$, 2004 - there were approximately fifteen students in attendance, the majority of whom were female. The research team had planned to address some of the students' concerns about the nature of our research project. They wanted to know what, exactly, we were doing there; what we were expecting of them; and how we planned to 'write them up'. We had planned to then continue to observe and work with them on their assigned classroom activities for the day. As per our usual experiences at MHS, however, that is not what happened. While we did begin discussing the ethics and politics of research, and restated our goal to observe how youth in drama classrooms made sense of their (fictional and actual) worlds, our conversation soon took an entirely unanticipated direction. 
The shift in focus brought us to a rich and heated conversation about racism, discrimination, and the merits/perils of 'African History Month' which, in North America, is celebrated in February. African History Month was instituted in Ontario high schools in the 1980s, at the height of celebratory multiculturalism, or what Enid Lee has referred to as the 'heroes and holidays' movement of multiculturalism (cf. Lee, Menkart, \& Okazawa-Rey, 1998).

A telling feature of many high school classroom discussions of racism is the temptation to find a conclusion that places those present outside the stream of history. High school students have been well schooled in the discourses of multiculturalism, which allow us to define ourselves as exceptional, as somehow more enlightened than our predecessors, and therefore not implicated in what was, after all, none of our doing (see Gallagher and Lortie, 2007 forthcoming). In this particular classroom, the students were questioning the very idea of an 'African History Month'. They were arguing about whether White students should be involved in the day's activities (e.g. cultural performances, school assemblies on anti-racism) at all, and whether or not White people in positions of power namely, George W. Bush - should formally apologize for slavery:

Loralei (Black, female, new immigrant, born in the ex Congo, moved from South Africa, to Belgium, to Canada, grade twelve Middleview student): "I will not apologize". Yeah he said it at a press conference recently or something. You "freed" them, yeah, but even when they were "free" it didn't change the fact that they're Black. And it matters. It even still matters now. They built that county on slaves, you know what I'm saying? 
Sabicca (Black, female, first-generation Canadian, Caribbean descent, grade twelve Middleview student): Yeah. So did England so the Queen could steal African gold and diamonds.

Kayla (Black, female, first-generation Canadian, Caribbean descent, grade twelve Middleview student): Why does Bush have to apologize for slavery? What did he do? Was he a part of it?

It was an impassioned discussion. Familiar themes of colour-blindness and meritocracy began to emerge. For example, one Black female student suggested that we shouldn't care about the skin colour of people, as long as they want to help with the African Heritage Club. A Black boy argued that there was nothing wrong with a White person owning a Black television station or magazine. There are many ways that one might read this particular response. It could signal the strategic positioning that minoritized students often take when White middle-class multicultural ideology pervades classroom discourse. As Dei, Karumanchery and Karumenchery-Luik (2004) argue:

While we are made visible to our oppressor, the discursive formations that guide us with our oppressive milieu infuse us with a duality and a selfhatred that effectively separates us from our fellow oppressed and from a knowledge of our oppression. We are seen as other from both external sites of privilege and internalized sites of Diasporic identity (p.90) 
But taken at face value, some researchers might read this conversation as a victory for multiculturalism - as positive evidence of racial harmony and the elision of social differences - and not evidence of the powerful school processes of assimilation into White dominant culture (cf. Sleeter, 1993; Sleeter, 1994), or of the need to move multicultural education beyond "heroes and holidays" towards a questioning of how knowledge about social differences is constructed, reified and normalized within the context of unequal relations of power (cf. Britzman, Santiago-Valles, Jimenez-Munoz, \& Lamash, 1993). One White research assistant interjected that a successful media venture may not simply represent a White executive's business acumen, but may also be attributed to a racial inequity that is the living legacy of fifteen generations of slavery. At that moment, another Black female student asked about the reparation payments forty acres and a mule - that were never made. As just one 'representative' of millions of descendants of slaves, she suggested that she is owed something more than the 'freedom' to earn a wage. This comment touched off a debate concerning the metaphysical quandary of where to place the dividing line between past and present; of how to assess the impact of history on our present relations. Indeed, as Bhabha (1994) argues,

[i]f the order of Western historicism is disturbed in the colonial state of emergency, even more deeply disturbed is the social and psychic representation of the human subject (p. 41).

Students were divided over President Bush's, or any living person's, obligation to atone for something s/he did not do, but from which s/he either directly or indirectly benefits. They were arguing about the nature of citizenship and whether 
human rights and freedoms were yet, in our 'post-colonial', 'post-slavery' context, universally accessible.

At this point, we took the decision to move to a drama structure because we wanted to both capitalize on and complicate the students' adamant opinions by placing us within an embodied, theatrical context. Dialogue, in theatre, is more than mere dialogue; it is the action of the play. Our sense was that we might find a way, through physicalizing and making dialogic our problem, to challenge the grand narratives of individualism and personal responsibility that are typically summoned to represent some form of 'objective truth' and to negotiate more nuanced meaning with the students. In dramatic terms, this discussion formed the pretext for a scene we were now 'getting on its feet,' and similarly, as researchers, we were also now ready to test our assumptions, to move from fact gathering to theory-building. ${ }^{2}$ We wanted, as much as possible, to place our research act within that alternate setting to capture the process of students' own theory-building as they moved from what they represented as their beliefs and their opinions to what they could negotiate with each other, through the distancing mechanism of "the stage" and to tease out the paradoxes and ironies that lay between thought and action.

Here, we were most interested in exploring the related concepts of racism and privilege, and so we began with Augusto Boal's (1992) dramatic, pedagogical activity, which aims to stimulate imaginative thought about conflict

\footnotetext{
${ }^{2}$ For a fuller analysis of the idea of theory-building with youth, through drama research methods, see Gallagher and Lortie (forthcoming) Building Theories of their Lives: Youth Engaged in Drama Research. International Handbook of Student Experience in Elementary and Secondary School. D. Thiessen and A. Cooke-Sather (eds.). Springer Publishing.
} 
through inanimate objects. We asked the students to arrange a group of chairs in such a way that one chair would be clearly more powerful than all the others. After trying several different iterations, we eventually agreed that the configuration in which one chair stood upright in front of a row of 'bowing' chairs - they had been tipped forward to resemble kneeling figures - made it most obvious which chair had the power. We would incorporate this into our subsequent scene by requiring all entrants to bow to the President before being permitted to speak.

We were moving toward improvising a scene between the president and a representative from a coalition, who was making his case for reparations for the descendents of slaves. We wanted to create a scene in which someone who directly or indirectly benefited from exploitation of a group would meet with a representative of that group seeking a public apology and reparations:

Phil (White, male, American-born, research assistant. Standing, then bowing, then facing Andre, who is sitting in the 'powerful' chair): It's been documented that you've many years profited from our labour so how can you look at me, and say that it's "over"? When you look at any city street you see the effects, the effect that slavery has had. [long pause].

Andre (Male, African Canadian, grade 12 student) I understand that slavery has been... [pause] yeah, well with 4 million people I don't see how me apologizing will make them feel hot. 
Phil: Well, we're saying that it will. It will allow us to, at least, begin some discussion about where we go from here. Without that, all it looks like is we have a hostile, White administration.

Andre: Well I'm very sorry but... apologies are... unnecessary. If you start, I can help you with whatever you want but apologies are out of the question.

What we came to realize in the abstracted discussion about power, through the concrete use of chairs and the early moments of a dialogue between the two characters, is that drama is a very potent research modality for those particularly interested in negotiating meaning with research participants, because it doesn't treat words and experiences as knowledge but as a place to begin inquiry (see Gallagher forthcoming 2007). We turned toward this 'drama research method' because we wanted to make the now trendy expression of 'coresearch' mean something. In other words, simply calling ourselves coresearchers did not make it so. We never lost sight of the power dynamics at work in calling ourselves co-researchers. We developed, dramatically, an exploration of the ideas we were getting from students to change the terms of communication and engage them in the analysis of data. We wanted to make theoretically and contextually rich the experiences we were having with the youth in our study and to let their words not simply "illustrate" our categories of understanding, but also interact with the complexities of the research, the 
philosophical dimensions of our inquiry, and our own theoretical constructions as researchers.

In the following section, we offer a second empirical example to further illustrate the contested terrain of citizenship and social justice in diverse urban high schools, particularly when racialized and gendered dramatic representations of citizenship deliberately and effectively challenge the audience's constructions of the performer, and of themselves.

\section{Da Kink in My Hair and Social Injustice}

As evidenced by the African History Month conversation, the larger social milieu at MHS is a very particular one: the relationships among the students' positioned identities (by race, class, sexuality, gender etc.) mean that there are real concerns about social discrimination at the school. We are not arguing, however, that these social locations fix students, but that they represent a dynamic social context in which students negotiate relationships and meanings. As Britzman, et al. (1993) argue, “...identities suggest more about social effects of political production than they do about essential selves" (p. 199). In particular, issues of racism and sexism were what prompted the Drama teacher at MHS, 'Ms. S' (a pseudonym), to choose the play Da Kink in My Hair as that year's student dramatic performance. Da Kink in My Hair shares the stories - both joyful and tragic - of a group of Black women who are clients at a West Indian hair salon in Toronto. Through the diverse cast of characters that enter the salon (each of whom has a monologue) the play explores various issues such as sexual 
orientation and homophobia, child molestation, the sheer joy of female companionship and, ultimately, learning how to feel comfortable in one's own skin.

When the play was presented to the school, there were accusations of "reverse racism", and "pushing an agenda", levelled against Ms. S (a white teacher), not only because she chose to show Da Kink at the school, but also because she chose to enter it in Ontario's Sears Drama Festival ${ }^{3}$. Anti-racist theorists Dei et al (2004) consider that the socially charged label of "reverseracism" effectively mutes groups' attempts to access full and unimpeded citizenship (cf: Fish, 2000). Ms S's students only performed a few of the monologues from Da Kink for the school, partly because "[s]ome of the monologues read and hear very controversially to the audience depending on what audience it is" (Personal correspondence with Ms S, Spring 2006), and partly because

the performance space [at Middleview High] is not [a] very adequate space to perform things because it cuts the audience too much off from the play so that if it's a controversial play or even if it's just a play then um the students have a certain anonymity within the audience and they can call stuff out and say rude things to the actors [...] (Interview with Ms S April/May, 2004).

The monologues that the students shared with the school told the stories of three different Black women, of varying ages and social positionings: one whose boyfriend left her for a White woman, after she had held numerous cleaning jobs in order to support him while he was in medical school; another whose teenaged son had been shot and killed by police officers when they

\footnotetext{
${ }^{3}$ The Sears Ontario Drama Festival is a prestigious competition which recognizes theatrical achievement in more than 300 of Ontario's high school Drama programs and clubs.
} 
mistook him for someone else ${ }^{4}$; and a third woman with a Ph.D. in Economics, who was under such pressure from the various stressors in her life, that she contemplated committing suicide:

Sherelle: My legs fell off three months ago you know? My arm just disappeared last week. And yesterday I reached for my coffee and my fingers fell off one by one and nobody noticed. Nobody noticed I was gone. Just gone... (Anthony, 2001, pp. 28-29) Ms. S. noted later that, "...even in my choices [of monologue], you can see that I am operating with a limiting sense of what is and is not tolerated at my school." (ibid.). And, indeed, at the MHS performance, many of the students did have strong reactions to those monologues, which they expressed through cheering, jeering, and making negative comments about the performers on stage.

Further, once the students and teachers began accusing Ms. S. of reverse racism and discrimination, she began to notice just how deeply divided MHS was in terms of race, and how all it took for those divisions to become clear was an abbreviated performance of Da Kink in My Hair. After the school assembly performance, many of Ms S's colleagues approached her to express their opinions about how "racist" and "sexist" (also of the reverse kind) they found the play. Not only did this put Ms. S. in a rather defensive position with her colleagues, but she was also concerned that Middleview High's administration would prohibit her from rehearsing the play for the Sears Festival. As Gallagher

\footnotetext{
${ }^{4}$ It is interesting to note that when the play was published, this monologue was later changed to have the boy die at the hands of another young Black male. This change reflected the playwright's more immediate concerns about the increase of so-called 'black-on-black' crime in Toronto at the time.
} 
pointed out during an interview with Ms. S, in this situation, there were serious issues of power at work. Ms. S agreed, saying that, "[...] you can't always orient yourself according to power, but we do all the time, I'm sure. In so many different ways" (Interview, April/May, 2004). In other words, when you expand the notion of citizenship and make White privilege visible, there is a price to be paid, as the social hierarchy re-asserts itself.

When asked what her response was to her colleagues' accusations of "reverse racism" and discrimination, Ms. S. offered the following example:

[...] this one teacher kept talking to me about it and then brought me her students' essays and said, "these are very well-written and they point to exactly what was reverse racist about your play." And so she gave me her students' essays, [saying] "They're excellent, they're very well-argued," and, so you know, I would go and find my own articles, written not by students but by professionals, you know, and I said, "Well this is an article from Professor So-and-So from Yale and he argues very well that reverse racism isn't even a term." So I just, you know, if you give me an article, I will give you a better one. (Interview, April/May, 2004)

Ms S, we note, turned to 'the authorities' for support; the popular discourses of school, and even a school as diverse as MHS, were so obviously blind to the ubiquitous force of White and masculine privilege that she found little support there.

What makes this event even more contentious (and delicious, in our view), was that not only did the Middleview High's performance of Da Kink in my Hair win the first level of competition at the Sears Drama Festival (one adjudicator was particularly impressed by how honest and committed the students were to the words they were speaking) but, at around the same time, the rights to the play were sold to Mirvish Productions, one of the most well-established and 
mainstream theatre production companies in Canada. At this, the head of the Sears Festival commented that Middleview High had "[...] scooped David Mirvish" (interview with Ms. S., April/May, 2004). In Ms. S's view, these two occurrences were a vindication of sorts, because it demonstrated to her colleagues that her decision to select Da Kink for Middleview's school play that year was not an attempt to further her own, 'pet', political agenda but, rather, to have her students perform a play that was, in her words, "great theatre" (Interview, April/May, 2004). She continued,

I think that play had just about everything in it that you could possibly imagine; like it broke every taboo, and I was always worried about breaking taboos and [now] I see that you can do it as long as it's good theatre (Interview, April/May, 2004).

\section{'Good theatre': Implications for 'Multiculturalism'}

Note that Ms. S. remarks that it is okay to break taboos in theatre, as long as it's 'good'. But, what is 'good theatre'? If its criteria obscure what Neelands (2004) refers to as...

the distinctive and preferred values, ethics and aesthetics of the [audience] and how [their] socially-constructed subjectivities [shape] pedagogical actions, intentions, and the interpretations and presentation of [...] drama (Neelands, 2004, p. 48).

...then, in the case of MHS, what does it mean to produce and perform 'good theatre' in such an ethno-racially divided context? What kinds of citizenship, then, might be privileged over others? Many in the school had an overtly negative reaction to the drama students' performances of the three monologues from the play. Prior to the performance, Ms. S had suspected that the responses to $D a$ Kink may not be favourable: in a post-performance reflection, she wrote "... [I] 
knew that some of the content was going to be controversial, and I did not want the administration to shut down the play before it went to the Sears Drama Festival" (Personal correspondence, Spring 2006). We were left to wonder whether the play so completely interrupted the comfortable and race-neutral discourses of multiculturalism, and the normative practices of Othering that obscure the relations of domination so often left unimpeded by traditional multiculturalism, that it could not be tolerated in the larger community.

What impact, then, does such 'controversial theatre' have on inclusive and productive forms of citizenship in schools? One might argue that structuring the play around a series of monologues only served to position each character as an object; in the case of Da Kink, as an object of racial victimization. Once again, Bhabha (1994b) provides a useful analytical construct: he argues that, when considering issues of identity, visibility, and the power/privilege of the colonial gaze, "scene" and "seen" become very important homonyms. Drawing from Fanon, Bhabha maintains that "scene" and "seen" speak to the necessity of surveillance in colonial discourse, in order to "see" (that is, to look at, to fix) the Other, as a colonial object of both fear and desire. This process is quite ambivalent, however, because it requires the consent - perceived or actual - of the objectified Other to be "seen" in the first place.

Thus, it could also be argued, that the monologues imbued the characters with a form of subjecthood: their stories, and their stories alone, were heard without interruption or silencing, thus placing them in opposition to 'established knowledge', challenging that knowledge's dominant narrative(s), and demanding 
that both how the stories are told, and how they are heard, get considered (Razack, 1998). This forces the audience to attend to the characters' stories differently because, as Verdecchia (2003) writes, "[t]he act of staging the lives of the 'marginal' changes the terms of reference" (p. 140); here, he is speaking of the "minority vs. majority" social relationship, wherein - conventionally - the experiences of the former are "consumed" by the latter (cf. hooks, 1992), as part of "[...] the complexity and contradictions of [the] desire to see, [and] to fix cultural difference in a continuable, visible object (Bhabha, 1994, p. 50, original emphasis).

So, consider, again, the discourse of "reverse racism" that was appropriated by (mostly, but not exclusively) White teachers at MHS: if one looks closely, one might see how that discourse works to deny or obscure those teachers' own complicity - as members of a dominant social group - in supporting racist structures and practices. By labelling something else as "racist", and then setting themselves in opposition to it, those teachers conveniently, even if unconsciously, prevented themselves from reflecting upon (as in critically engaging with - see: Verdecchia, 2003) what a play like Da Kink in My Hair might mean for White audience members. As a further example of this, consider the response of one of the (White) adjudicators of the Sears Festival competition that the MHS students won that year: his comments to the actors focused mainly on how "great" it was to see brown and black, multicultural faces on stage, instead of on the quality of the students' performances. This reaction reveals the problematic (multicultural) perspective that 'surface quality' 
diversity is enough to eliminate racial discrimination; or, at the very least, it is enough to signal that racial discrimination is coming to an end. Such a response also typifies Trinh's (1989) “...anonymous, all-male, and predominantly white collective identity..." (p. 48, original emphasis), which she resents: not because of

... his inheritance of a power he so often disclaims, disengaging himself from a system he carries with him, but [because of] his ear, eye, and pen, which record in his language while pretending to speak through mine, on my behalf (ibid.).

In more tangible terms, the adjudicator's response hearkens back to earlier notions of celebratory multicultural discourses that, as many have argued, do nothing to critically interrupt unequal power relations. Razack (1998) argues that such an approach to/perspective on cultural difference only serves to ... reinforce an important epistemological cornerstone of imperialism: the colonized possess a series of knowable characteristics [such as the "Black and Brown" faces of the students who performed Da Kink] and can be studied, known, and managed accordingly by the colonizers, whose own complicity remains unmasked (p. 9, emphasis added)

Indeed, Ms. S. revealed that she "...kept thinking, 'When is this guy going to get over seeing multicultural faces and start talking about theatre?"' Or, as one might have asked, "When is this guy going to get over seeing multicultural faces and start talking about the politics of theatre?" That is, the politics of his own complicity as a White audience member who is "consuming" the stories of racially marginalized Others; or, the politics that might have led to Trey Anthony's comment that the reason she was able to sell the rights for Da Kink in My Hair to Mirvish Productions was because "... it broke records wherever it went. It sold 
out and it was going to bring [the Mirvishes] that urban audience they were looking for." 5

Whatever their different (and differently motivated) responses, the teachers at MHS, the adjudicator at the Sears Festival, the decision-makers at Mirvish Productions were all gazing upon 'the Other' as objects - "captured, solidified, and pinned to a butterfly board" (Trinh, 1989, p. 48) - and as subjects, in their own right. To look upon the other is always a political act. But seeing 'Others' as subjects, as both playwright Trey Anthony and drama teacher Ms S have done, brings into view what Rivière (2006) refers to as the "limits of 'representational tolerance'”: that is, in a dramatic performance, how much deviation from the actual norms of a given society is considered acceptable by the audience? Not only does the answer to this question speak to societal ideologies and values, it also exposes the potential costs - to performers, to audience members and, as the example of Middleview High shows, to Drama teachers - of using Drama to push boundaries, break taboos, and “...highlight the fitful, incomplete, [and] reciprocal relations between the colonizer and the colonized" (McCarthy, Giardina, Harewood, \& Park, 2005, p. 159).

Indeed, both the episodes described in this article were catalysts for recognizing how drama, as teaching practice and as research method, is an ongoing quest, an on-going set of complex relations, an upsetting of notions of authority, and something which most certainly does not fit into tidy positivist scientific/educational discourses. In our argument here 'rocking the boat' in the

\footnotetext{
${ }^{5}$ Source: http://www.afrotoronto.com/Articles/TreyAnthony.html
} 
drama classroom- through our uses of drama as method in research with youth and through Ms S's desire to theatrically represent for her school community issues of cultural relevance to her students- has exposed multiculturalism in ways that trouble simplistic notions of citizenship and romantic notions of social cohesion. ... 


\section{Works Cited}

Boal, A. (1992). Games for actors and non-actors (A. Jackson, Trans.). London and New York: Routledge.

Gallagher, K. (forthcoming 2007) The Theatre of Urban: Youth and Schooling in Dangerous Times. Toronto, London, Buffalo: University of Toronto Press.

Gallagher, K. (in press, 2006) Building Theories of Their Lives: Youth Engaged in Drama Research. International Handbook of Student Experience in Elementary and Secondary School. D. Thiessen and A. Cooke-Sather (eds.). Springer Publishing.

Anthony, T. (2001). Da kink in my hair. Toronto, ON: Playwrights Canada Press.

Bhabha, H. (1994). Interrogating identity: Frantz Fanon and the postcolonial prerogative. In The location of culture (pp. 40 - 65). London, UK: Routledge.

Britzman, D., Santiago-Valles, K., Jimenez-Munoz, G., \& Lamash, L. M. (1993). Slips that show and tell: Fashioning multiculture as a problem of representation. In C. McCarthy \& W. Crichlow (Eds.), Race, identity, and representation in education (1st ed., pp. 188 - 200). New York, NY; London, UK: Routledge.

Dei, G. J. S., Karumanchery, L., \& Karumanchery-Luik, N. (Eds.). (2004). Playing the race card: Exposing White power and privilege. New York, NY: Peter Lang Publishing.

Fish, S. (2000). Reverse racism, or how the pot got to call the kettle black. The New Crisis, 107(1), 14 - 21.

Giroux, H. (1992). Border crossings: Cultural workers and the politics of education. New York, NY; London, UK: Routledge.

hooks, b. (1992). Eating the other: Desire and resistance. In Black looks: Race and representation (pp. 21 - 39). Boston, MA: South End Press.

Lee, E., Menkart, D., \& Okazawa-Rey, M. (Eds.). (1998). Beyond heroes and holidays: A practical guide to $\mathrm{K}-12$ anti-racist, multicultural education and staff development. Washington, DC: Network of Educators on the Americas.

McCarthy, C., \& Crichlow, W. (Eds.). (1993). Race, identity, and representation in education (1st ed.). New York, NY; London, UK: Routledge.

McCarthy, C., Giardina, M. D., Harewood, S. J., \& Park, J.-K. (2005). Contesting culture: Identity and curriculum dilemmas in the age of globalization, postcolonialism, and multiplicity. In C. McCarthy, W. Crichlow, G. Dimitriadis \& N. 
Dolby (Eds.), Race, identity, and representation in education (2nd ed.). New York, NY; London, UK: Routledge.

Neelands, J. (2004). Miracles are happening: Beyond the rhetoric of transformation in the Western traditions of drama education. Research in Drama Education, 9(1), 47 - 56.

Razack, S. (1998). Looking White people in the eye: Gender, race and culture in courtrooms and classrooms. Toronton, ON: University of Toronto press.

Rivière, D. (2006). Performed identities: Drama and the transformation of multicultural education. Unpublished Doctoral thesis, Ontario Institute for Studies in Education/University of Toronto, Toronto, ON.

Sleeter, C. E. (1993). How white teachers construct race. In C. McCarthy \& W. Crichlow (Eds.), Race, identity, and representation in education (1st ed., pp. 157 - 171). New York, NY; London, UK: Routledge.

Sleeter, C. E. (1994). White racism. Multicultural education(Spring), 5 - 8.

Trinh, T. M.-H. (1989). Woman, native, other. Bloomington \& Indianapolis, IN: Indiana University Press.

Verdecchia, G. (2003). Seven things about Cahoots Theatre projects. In K. Gallagher \& D. Booth (Eds.), How theatre educates: Convergences and counterpoints with artists, scholars and advocates (pp. 133 - 143). Toronto; Buffalo; London: University of Toronto Press.

Yon, D. A. (2000). Elusive culture: Schooling, race, and identity in global times. Albany, NY: State University of New York Press. 